\title{
The phylogenetic position of the enigmatic Atlantic forest-endemic spiny mouse Abrawayaomys (Rodentia: Sigmodontinae)
}

\author{
Karen Ventura ${ }^{1}$, Maria José J Silva ${ }^{2}$, Lena Geise ${ }^{3}$, Yuri LR Leite ${ }^{4}$, Ulyses FJ Pardiñas ${ }^{5}$, Yatiyo Yonenaga-Yassuda ${ }^{1}$ \\ and Guillermo D'Elía ${ }^{*}$
}

\begin{abstract}
Background: The phylogenetic position of the sigmodontine genus Abrawayaomys, historically assigned to the tribe Thomasomyini or considered a sigmodontine incertae sedis, was assessed on the basis of nuclear and mitochondrial DNA sequences obtained from four individuals from different localities in the Atlantic forest of Brazil. Sequences of Abrawayaomys were analyzed in the context of broad taxonomic matrices by means of maximumlikelihood (ML) and Bayesian analyses (BA).

Results: The phylogenetic position of Abrawayaomys differed depending on the gene analyzed and the analysis performed (interphotoreceptor retinoid-binding protein (IRBP) ML: sister to Thomasomyini; IRBP BA: sister to Akodontini; cytochrome (Cyt) b ML: sister to Neotomys; and Cyt b BA: sister to Reithrodontini). With the sole exception of the BA based on Cyt $b$ sequences, where the Abrawayaomys-Reithrodon clade had strong support, all sistergroup relationships involving Abrawayaomys lacked any significant support.

Conclusions: As such, Abrawayaomys constitutes the only representative so far known of one of the main lineages of the sigmodontine radiation, differing from all other Atlantic forest sigmodontine rodents by having a unique combination of morphological character states. Therefore, in formal classifications, it should be regarded as a Sigmodontinae incertae sedis.
\end{abstract}

Keywords: Akodontini; Atlantic forest; Cricetidae; Phylogeny; Thomasomyini

\section{Background}

With about 86 living genera, cricetids of the subfamily Sigmodontinae are one of the most diversified and taxonomically complex groups of mammals. Predominantly distributed in South America, sigmodontines also reach Central and North America, and one extant genus is endemic to the Galapagos Islands (D'Elía 2003a). Remarkably, new sigmodontine genera are still being erected on the basis of both revisionary museum work and from newly discovered species (e.g., Pardiñas et al. 2009a; Percequillo et al. 2011; Pine et al. 2012; Alvarado-Serrano and D'Elía 2013; see comments in D'Elía and Pardiñas 2007). Similarly, statuses of several sigmodontine taxonomic forms at

\footnotetext{
* Correspondence: guille.delia@gmail.com

${ }^{6}$ Instituto de Cs. Ambientales y Evolutivas, Facultad de Ciencias, Universidad Austral de Chile, Valdivia 5090000, Chile

Full list of author information is available at the end of the article
}

the species level are unclear (e.g., Alarcón et al. 2011; Bonvicino et al. 2012).

Sigmodontine genera have been arranged into different groups, most of which have been given the formal rank of tribes (e.g., Reig 1980). In the last two decades, phylogenetic analyses using either morphological or molecular data or both were used to set the limits and contents of these groups and determine the timing of their diversification (e.g., Braun 1993; Smith and Patton 1999; Steppan 1995; D'Elía 2003b; Pacheco 2003; Weksler 2003; D'Elía et al. 2003, D'Elia et al. 2006a, b; Martínez et al. 2012; Parada et al. 2013; Salazar-Bravo et al. 2013). Those studies caused a number of major reconsiderations on the limits and contents of these groups. Currently, 12 extant genera are considered as Sigmodontinae incertae sedis (see the most recently published classification in D'Elía et al. (2007) and the modification prompted by the description of a new 
genus by Alvarado-Serrano and D'Elía (2013)); one of these is Abrawayaomys Cunha and Cruz 1979.

Abrawayaomys is a poorly known sylvan sigmodontine genus that stands out within the sigmodontine radiation due to its spiny pelage and unusual craniodental morphology. It is found in the Atlantic forest of Argentina and Brazil and is known from a handful of trapped specimens and a few osteological remains gathered from owl pellets (Pardiñas et al. 2009b). Two species are recognized: the type species Abrawayaomys ruschii Cunha and Cruz 1979 and the recently described Abrawayaomys chebezi (Pardiñas et al. 2009a, 2009b).

Abrawayaomys displays a striking combination of morphological features that was referred by Musser and Carleton $(2005$, p. 1,088) in the following terms 'Diagnostic traits seem to combine aspects of Neacomys, Oryzomys, and Akodon, and both Reig (1987) and Smith and Patton (1999) acknowledged the enigmatic affinities of Abrawayaomys as uncertain.' Recently, Pardiñas et al. (2009b) evaluated the morphology of Abrawayaomys in detail and noted a certain resemblance to the bauplan of the tribe Akodontini but also to the thomasomyine genera Chilomys and Rhagomys. Similarities with Akodontini were regarded as convergences since Abrawayaomys was assigned to Thomasomyini given that independent sets of data placed Chilomys and Rhagomys in Thomasomyini (D'Elía et al. 2006a; Salazar-Bravo and Yates 2007) and because morphology-based phylogenetic analyses placed Abrawayaomys in this tribe (Pacheco 2003; Salazar-Bravo and Yates 2007). The lack of molecular data for Abrawayaomys has prevented an assessment of its position within the available comprehensive sigmodontine trees generated on the basis of mitochondrial and nuclear DNA sequences (e.g., Engel et al. 1998; Smith and Patton 1999; D'Elía 2003b; Weksler 2003; D'Elia et al. 2006a, b).

In recent fieldwork in the states of Rio de Janeiro (Pereira et al. 2008), Minas Gerais (Passamani et al. 2011), and São Paulo (see below) in southeastern Brazil, four specimens referred to as $A$. ruschii were collected. Based on mitochondrial and nuclear DNA sequences gathered from these specimens, we present the first phylogenetic analyses to test previous hypotheses concerning the placement of Abrawayaomys within the sigmodontine radiation. In addition, we provide some taxonomic judgments based on the resulting phylogeny and comments on the evolution of some morphological traits.

\section{Methods}

DNA sequences corresponding to the cytochrome (Cyt) $b$ gene and the first exon of the nuclear interphotoreceptor retinoid-binding protein (IRBP) gene were used as evidence. We sequenced four specimens of $A$. ruschii deposited in the following Brazilian collections: Museu Nacional, Univ. Federal do Rio de Janeiro (MN 67557; Brazil, Rio de Janeiro, Aldeia Sapucai) (Pereira et al. 2008); Museu de Zoologia, Univ. de São Paulo (MZUSP 32319; Brazil, São Paulo, Biritiba-Mirim; BO 27; Brazil, São Paulo, Estação Ecológica de Boracéia); and Coleção de Mamíferos da Univ. Federal de Lavras (CMUFLA 906; Brazil, Minas Gerais, Caeté) (Passamani et al. 2011). Sequences were gathered following the protocol of Pardiñas et al. (2003) and D'Elía et al. (2006b). We found minor differences among Cyt $b$ sequences (see 'Results' below), but in the phylogenetic analyses, we used that of specimen MN 67557 because it was the only complete one (i.e., 1,140 bp; the other being $801 \mathrm{bp}$ long). We found no variation in IRBP sequences of the four specimens analyzed, and therefore, Abrawayaomys was represented by a single terminal (MN $67557)$ in the phylogenetic analyses. New sequences were submitted to GenBank [GenBank: JX949182 to JX949189].

To appraise the phylogenetic position of Abrawayaomys within the radiation of the Sigmodontinae, we sought to ensure that sigmodontine diversity was represented as comprehensively as possible. According to the current classification, our sampling only lacked for both matrices the incertae sedis genera Phaenomys and Wilfredomys; the akodontines Gyldenstolpia and Podoxymys; the ichthyomyines Anotomys, Chibchanomys, Neusticomys, and Ichthyomys; and the oryzomyine Mindomys. In addition, the IRBP matrix lacked the thomasomyine Chilomys. Meanwhile, the ichthyomyine Rheomys, the oryzomyine Microakodontomys, and the thomasomyine Aepeomys were also missing from the Cyt $b$ matrix. Therefore, both the IRBP $(1,181$ characters) and Cyt $b$ (1,134 characters) matrices respectively included representatives of 76 and 74 sigmodontine genera (including sequences of the recently described genus Neomicroxus). The IRBP matrix lacked a sequence for Neusticomys available in GenBank [GenBank: EU649036] because a recent inspection of it indicated that it may be in fact a composite of an ichthyomyine and an oryzomyine sequence. Although the monophyly of the Sigmodontinae is well corroborated (e.g., Engel et al. 1998; Steppan et al. 2004; Parada et al. 2013), the identity of its sister group is unclear. Therefore, we integrated the outgroup with two representatives of each of the other four main lineages that, together with the Sigmodontinae, compose the family Cricetidae: arvicolines (Arvicola and Microtus), cricetines (Cricetulus and Phodopus), neotomines (Neotoma and Scotinomys), and tylomyines (Nyctomys and Tylomys). All taxa represented in the analyses, along with the GenBank accession numbers of their DNA sequences, are listed in Table 1.

Alignment was done with Clustal X (Thompson et al. 1997) using default parameters for all alignment parameters. Uncorrected genetic distances ( $p$ distances) with pairwise deletions were computed using MEGA 5 (Tamura et al. 2011). Each matrix was subjected to maximum-likelihood (ML) (Felsenstein 1981) and Bayesian analyses (BA) 
Table 1 List of taxa and the DNA sequences of which were included in the phylogenetic analyses

\begin{tabular}{|c|c|c|c|}
\hline Tribe & Species & IRBP & Cyt $b$ \\
\hline Abrotrichini & Abrothrix longipilis & AY163577 & U03530 \\
\hline Abrotrichini & Chelemys macronyx & AY277441 & U03533 \\
\hline orotrichini & Geoxus valdivi & AY277448 & AY275116 \\
\hline Abrotrichini & Notiomys edwardsii & AY163602 & U03537 \\
\hline brotrichini & Pearsonomys annectens & AY851749 & AF108672 \\
\hline Akodontini & 'Akodon' serrensis & EF626799 & AY273908 \\
\hline Akodontini & Akodon azarae & AY163578 & DQ444328 \\
\hline kodontini & Bibimys chacoensis/labiosus & AY277435 & DQ444329 \\
\hline Akodontini & Blarinomys breviceps & AY277437 & AY275112 \\
\hline kodontini & Brucepattersonius soricinus & AY277439 & AY277486 \\
\hline kodontini & Deltamys kempi & AY277444 & AY195862 \\
\hline Akodontini & Juscelinomys huanchacae & AY277453 & AF133667 \\
\hline kodontini & Kunsia tomentosus & AY277455 & AY275120 \\
\hline Akodontini & Lenoxus apicalis & AY277456 & U03541 \\
\hline Akodontini & Necromys lasiurus & AY277459 & AY273912 \\
\hline kodontini & Oxym & 7468 & 51854 \\
\hline Akodontini & Scapteromys tumidus & AY163637 & AY275133 \\
\hline kodontini & radensis & AY277481 & AY273916 \\
\hline Akodontini & Thaptomys nigrita & AY277482 & AF108666 \\
\hline Ichthyomyini & Rheomys raptor & AY163635 & - \\
\hline Incertae sedis & Abrawayaomys ruschii & JX949185 & JX949189 \\
\hline Incertae sedis & Andinomys edax & JQ434400 & AF159284 \\
\hline Incertae sedis & Chinchillula sahamae & JQ434409 & JQ434422 \\
\hline Incertae sedis & Delomys sublineatus & AY163582 & AF108687 \\
\hline Incertae sedis & Euneomys chinchilloides & AY277446 & AY275115 \\
\hline Incertae sedis & Irenor & AY163587 & U03534 \\
\hline Incertae sedis & Juliomys pictipes & AY163588 & AF108688 \\
\hline Incertae sedis & Neomicroxus latebricola & QCAZ4160 & QCAZ4160 \\
\hline Incertae sedis & Neotomys ebriosus & HM061605 & HM061604 \\
\hline Incertae sedis & Punomys kofordi & JQ434414 & JQ434426 \\
\hline Dryzomyini & Aegialomys xanthaeolus & GQ178247 & EU579479 \\
\hline Oryzomyini & Amphinectomys savamis & AY163579 & EU579480 \\
\hline Oryzomyini & Cerradomys scotti & EU649040 & EU579482 \\
\hline Oryzomyini & s albimaculatus & EU & EU \\
\hline Oryzomyini & Eremoryzomys polius & AY163624 & EU579483 \\
\hline Oryzomyini & Euryoryzomys macconnelli & AY163620 & EU579484 \\
\hline Oryzomyini & Handleyomys intectus & AY163584 & EU579490 \\
\hline Oryzomyini & Holochilus brasiliensis & AY163585 & EU579496 \\
\hline Oryzomyini & Hylaeamys megacephalus & AY163621 & EU579499 \\
\hline Oryzomyini & Lundomys molitor & AY163589 & EU579501 \\
\hline Oryzomyini & Melanomys caliginosus & EU649052 & EU340020 \\
\hline Oryzomyini & Microakodontomys transitorius & EU649054 & - \\
\hline Oryzomyini & Microryzomys minutus & AY163592 & AF108698 \\
\hline Oryzomyini & Neacomys spinosus & AY163597 & EU579504 \\
\hline
\end{tabular}

Table 1 List of taxa and the DNA sequences of which were included in the phylogenetic analyses (Continued)

\begin{tabular}{llll}
\hline Oryzomyini & Nectomys squamipes & AY163598 & EU340012
\end{tabular}

Oryzomyini Nephelomys albigularis

EU649057 EU579505

Oryzomyini Nesoryzomys fernandinae

EU649058 EU579506

Oryzomyini

Oecomys bicolor

Oryzomyini

Oligoryzomys fulvescens

AY163604 EU579509

Oryzomyini

Oreoryzomys balneator

Oryzomyini

Oryzomys palustris

Oryzomyini

Pseudoryzomys simplex

Oryzomyini

Scolomys ucayalensis

Oryzomyini

Sigmodontomys alfari

Oryzomyini

Sooretamys angouya

Oryzomyini

Tanyuromys aphrastus

Oryzomyini

Transandinomys talamancae

AY163611 DQ227457

AY163617 EU579510

AY163623 EU074639

AY163633 EU579517

AY163638 EU579518

AY163641 EU340016

AY163616 EU579511

JF693878 JF693877

AY163627 EU579514

Oryzomyini Zygodontomys brevicauda

AY163645

EU579521

Phyllotini

Andalgalomys pearsoni

Phyllotini

Auliscomys pictus

EU649038

AF159285

Phyllotini

Calomys lepidus

Phyllotini

Phyllotini

Eligmodontia typus

Phyllotini

Galenomys garleppi

Phyllotini

Graomys griseoflavus

AY277434

JQ434420

AY163580

EU579473

AY277445

AF108692

JQ434410

JQ434423

EU649037 EU579472

AY277457 AY275122

Phyllotini

Loxodontomys micropus

AY163632 AY275128

Phyllotini

Phyllotis xanthopygus

Phyllotini

Salinomys delicatus

JQ434415

EU377608

Phyllotini

Tapecomys primus

JQ434416 AF159287

JQ434417 JQ434425

Reithrodontini Reithrodon auritus

AY163634

EU579474

Sigmodontini Sigmodon alstoni

Thomasomyini Aepeomys lugens

EU635698

AF293397

Thomasomyini Chilomys instans

Thomasomyini Rhagomys longilingua/rufescens

DQ003722

AF108679

Thomasomyini Rhipidomys macconnelli

AY206770

Thomasomyini Thomasomys aureus

Wiedomyini Wiedomys pyrrhorhinos

AY277483 U03540

AY163644 EU579477

Outgroup Arvicola terrestris

AY277407 AY275106

Cricetus cricetus

Microtus socialis

AY277410 AY275109

FM162055 AY513830

Neotoma albigula

AY277411 AF108704

Nyctomys sumichrasti

AY163603 AY195801

Phodopus sungorus

Scotinomys xerampelinus

AY163631 JN015007

AY277416 AF108706

Tylomys nudicaudus

AY163643 DQ179812

Sequences of the genera Bibimys and Rhagomys of each gene were gathered from different species. GenBank accession numbers for each gene (IRBP and Cyt $b$ ) are indicated in the last two columns. Tribal assignations follow D'Elía et al. 2007 (see also D'Elía and Pardiñas 2007) and results of the present study. 
(Rannala and Yang 1996). The ML analysis was conducted in Treefinder (Jobb et al. 2004; Jobb 2008). The best fitting models of nucleotide substitution (IRBP: TVM[Optimum, Empirical]:G[Optimum]:5; Cyt $b$ : GTR[Optimum, Empirical]:G[Optimum]:5) (see Jobb 2008) were selected with the Akaike information criterion in Treefinder using the 'propose model' routine. The best tree was searched under the model of nucleotide substitutions previously selected using search algorithm 2 implemented in Treefinder version March 2011; nodal support was estimated with 1,000 bootstrap pseudoreplicates (BS). The BA was conducted using MrBayes 3.1.2 (Ronquist and Huelsenbeck 2003) by means of two independent runs with three (IRBP) or seven (Cyt $b$ ) heated and one cold Markov chains each. Considering the model selected by Treefinder and models specified in MrBayes, a model with six categories of a base substitution, a gamma-distributed rate parameter, and a proportion of invariant sites was specified for both matrices; all model parameters were estimated using MrBayes. Runs were allowed to proceed for 20 million (IRBP) and 28 million (Cyt $b$ ) generations, and trees were sampled every 1,000 (IRBP) and 2,000 (Cyt $b$ ) generations. Log-likelihood values were plotted against the generation time to check that runs converged on a stable log-likelihood value. The first $25 \%$ of sampled trees were discarded as burn-in; the remaining trees were used to compute a $50 \%$ majority rule consensus tree and obtain posterior probability (PP) estimates for each clade.

\section{Results}

Cyt $b$ gene sequences of Abrawayaomys gathered from the three specimens collected in the states of São Paulo and Rio de Janeiro varied by $0.5 \% \sim 0.7 \%$; while comparisons involving the Cyt $b$ sequence of the specimen from Minas Gerais ranged $2.6 \% \sim 3.0 \%$. As mentioned above, IRBP sequences of the four specimens analyzed were identical.

Abrawayaomys, as represented by sequences of specimen MN 67557, was highly divergent from all compared sigmodontines for both analyzed genes. For the Cyt $b$ gene, observed pairwise values involving Abrawayaomys ranged $19.0 \%$ 25.9\% for comparisons with Neotomys and Lundomys. For the IRBP gene, observed pairwise values involving Abrawayaomys ranged 3.42\% 6.65\% for comparisons with Brucepattersonius and Rheomys.

Phylogenetic analyses recovered general results congruent with those of previous IRBP- and/or Cyt $b$-based studies (e.g., D'Elia et al. 2006a, b; Percequillo et al. 2011; Martínez et al. 2012; Parada et al. 2013; Salazar-Bravo et al. 2013). For descriptions and discussions of these findings (e.g., a strongly supported Sigmodontinae, a strongly supported Oryzomyalia, the polyphyly of the Reithrodon group, and differences between gene trees), we refer the reader to those studies because herein we focus on the phylogenetic position of Abrawayaomys.
Depending on the gene analyzed, the phylogenetic position of Abrawayaomys varied from being sister to Akodontini (IRBP BA; PP $=0.62$; Figure 1), sister to Thomasomyini (IRBP ML; BS < 50), sister to Reithrodontini (Cyt $b$ BA; PP = 0.98; Figure 2), or sister to Neotomys (Cyt $b$ $\mathrm{ML} ; \mathrm{BS}<50$ ). As noted, with the sole exception of the BA based on Cyt $b$ sequences, where the AbrawayaomysReithrodon clade had strong support, all sister-group relationships involving Abrawayaomys lacked any significant support. The most inclusive and well-supported clade containing Abrawayaomys was that corresponding to Oryzomyalia (sensu Steppan et al. 2004).

\section{Discussion}

The diversity of sigmodontine forms has long captivated students of New World mammals, but at the same time, it has seriously defied those attempting to classify them according to their evolutionary history. Problems range from species boundaries to relationships among species and genera, and limits and contents of higher taxa (e.g., tribes). These issues have direct implications for the study of the history of the diversification of the group, which in turn arguably constitutes one of the most controversial debates in muroid systematics (Voss 1993; D'Elía 2003b).

Herein, we showed that the phylogenetic position of Abrawayaomys varies from being sister to Akodontini, Thomasomyini, Reithrodontini, or Neotomys, depending on the gene analyzed (IRBP or Cyt $b$ ) and the analysis performed (ML or BA). Given that previous studies showed discrepancies between the topologies of different sigmodontine gene trees (e.g., Feijoo et al. 2010; Teta et al. 2011), the fact that different datasets (i.e., IRBP or Cyt $b$ matrices with slightly different taxonomic sampling) provide different relationships for Abrawayaomys is not unexpected. Importantly, with the exception of the BA based on Cyt $b$ sequences (sister to Reithrodontini), no sister relationship involving Abrawayaomys was recovered that had good support. In light of the analytical results, Abrawayaomys cannot be placed with certainty in any more inclusive clade than that of Oryzomyalia (sensu Steppan et al. 2004).

Pacheco (2003, p. 130), in a phylogenetic analysis based on morphological characters, found the genus Abrawayaomys to be sister to Rhagomys within the Thomasomyini clade. This relationship was supported by the following character states: a broad zygomatic plate, an interorbital region convergent with the supraorbital margins squared or weakly beaded, a long jugal, the absence of mesolophids (but see below), a masseteric crest anterior to the procingulum of the first lower molar, and a deeply excavated retromolar region of the mandible. Pacheco (2003) highlighted the retromolar region condition, i.e., broad and fenestrated, as a synapomorphy of Abrawayaomys + Rhagomys. We agree with Pacheco 


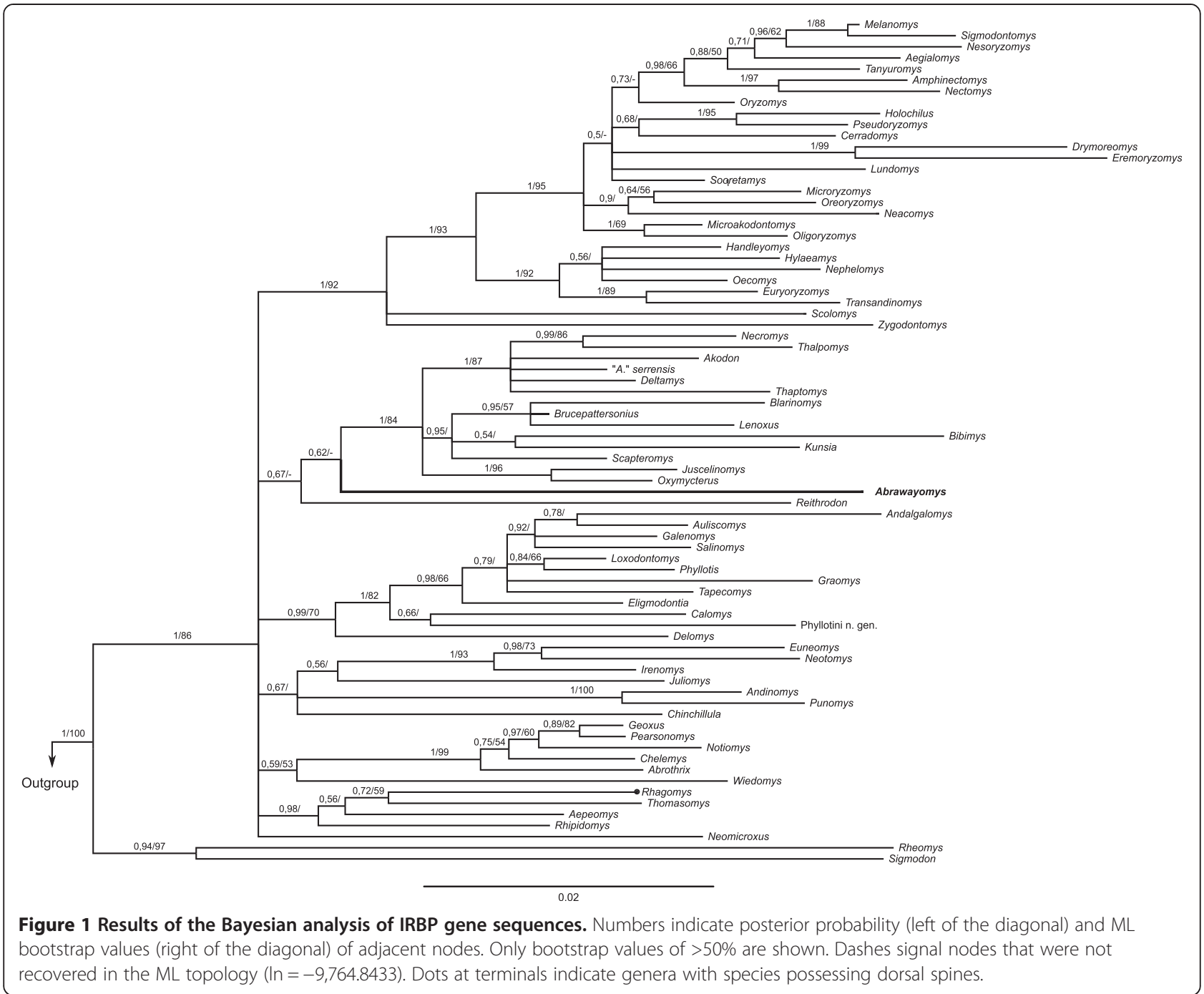

(2003) (see Musser and Carleton 2005) in the general resemblance between Abrawayaomys and Rhagomys and to a lesser extent to the remainder of the Thomasomyini, but we suggest that this similarity is not remarkable and more important and that these shared character states are not synapomorphies of a putative Abrawayaomys and Rhagomys clade. Almost all of those character states listed by Pacheco (2003) are also present in many sigmodontines, indicating the large amount of homoplasy existing within this group. In addition, we assert that the molar morphologies of both genera are quite distinct, having only the widespread brachyodont condition in common. Rhagomys has very well-developed mesolophs/phids (cf. Luna and Patterson (2003) vs. Pacheco (2003)), procingula of the first upper molars clearly crossed by a deep anteromedian flexus, well-developed posterolophs, a slightly reduced third lower molar with respect to the second lower molar, and several other traits found among taxa displaying the dental bauplan of the pentalophodont type (sensu Hershkovitz 1962), which is clearly distinguishable from the unequivocally tetralophodont molar of Abrawayaomys ( $c f$. Pardiñas et al. 2009b). Additional differences between these two genera are more than trenchant, including incisive foramina and palate extensions, parapterygoid plate morphology, and carotid circulatory pattern (Table 2) (see also Pardiñas et al. 2009b, Table three). Similarly, several trenchant character states are present in Abrawayaomys and representatives of other sigmodontine tribes. The external morphology of Abrawayaomys resembles that of many akodonts ( $c f$. Pereira et al. 2008, Figure one), although it has a moderately longer tail, at least in some individuals. A morphological description of the stomach (Finotti et al. 2003) suggests a hemiglandular-unilocular type, a widespread condition among sigmodontines (Carleton 1973). Finally, Pacheco (2003) also indicated that Abrawayaomys has a peculiar genal vibrissa (called genal vibrissa 2), which is also present in the oryzomyine Oecomys and 


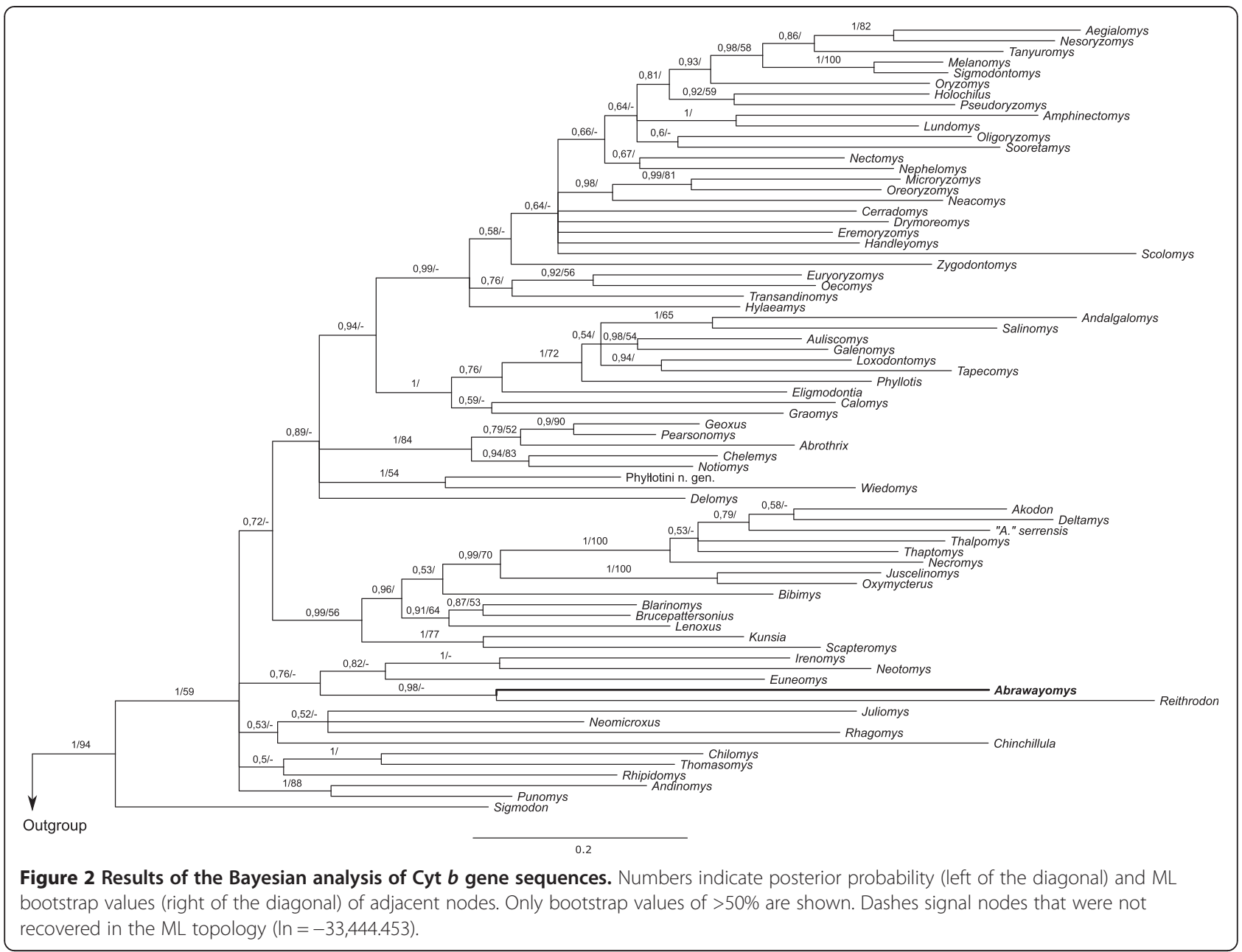

the akodontine Kunsia, and a reduced fifth pedal digit. Similarly, karyotypic evidence sheds no conclusive light on the phylogenetic position of Abrawayaomys, as the diploid number of $2 \mathrm{n}=58$ (Pereira et al. 2008) found in A. ruschii is also present in several distantly related oryzomyine species, such as Euryoryzomys lamia (Andrades-Miranda et al. 2000), Holochilus brasiliensis (Yonenaga-Yassuda et al. 1987), Nectomys squamipes (Yonenaga-Yassuda et al. 1987), Oecomys trinitatis (Patton et al. 2000), Oligoryzomys chacoensis (Myers and Carleton 1981), and Sooretamys angouya (Andrades-Miranda et al. 2000). Taking all this evidence as a whole, Abrawayaomys cannot be placed with certainty in any clade less inclusive than the large clade Oryzomyalia (see also Voss 1993). Therefore, in light of all of the evidence at hand, in formal classifications, Abrawayaomys should be kept as an incertae sedis sigmodontine (D'Elía et al. 2007). Results of future phylogenetic analyses, especially those including sequences of two other Atlantic forest inhabitants, Phaenomys and Wilfredomys, which were also considered part of the tribe Thomasomyini (e.g., Pacheco 2003) and are now regarded as Sigmodontinae incertae sedis (e.g., D'Elía et al. 2007), may prompt changes in this classification.

The prevailing biogeographic view is that the Andes played a major role in sigmodontine diversification, in which the main sigmodontine lineages originated there and later colonized lowlands of South America (Reig 1984, 1986; see also Salazar-Bravo et al. 2013). However, Abrawayaomys, an Atlantic forest endemic, is the sole living representative of one of the main sigmodontine lineages (i.e., those classified at the tribal rank in formal classifications or those genera that do not belong to any recognized tribe). A similar scenario was found for two other Atlantic forest endemics, the genera Delomys and Juliomys (Figures 1 and 2) (Voss 1993; D'Elía et al. 2006a; see also the classification in D'Elía et al. 2007). The other main sigmodontine lineages are distributed outside the Atlantic forest (e.g., Abrotrichini and Sigmodontini) or, even when present in this biome, are not endemic to it (e.g., Akodontini and Oryzomyini). As mentioned above, the Atlantic forest-endemic Phaenomys and mostly Atlantic forest-resident Wilfredomys have not been included in any molecular-based phylogenetic analysis. Until their 
Table 2 Morphological comparisons among Abrawayaomys and other members of the Sigmodontinae

\begin{tabular}{|c|c|c|c|c|c|c|c|}
\hline Character & Abrawayaomys & Rhagomys $^{\mathrm{b}}$ & Phaenomys $^{\mathrm{d}}$ & Thomasomys $^{\mathrm{f}}$ & Aepeomys $^{9}$ & Akodon & Reithrodon \\
\hline Plantar pads & 6 & 6 & 6 & 6 & 6 & 6 & 4 \\
\hline Hindfoot surface & Smooth? & Smooth & Squamated & Smooth & Smooth & Squamated & Squamated \\
\hline Mammae & $6 a$ & 6 & 8 & 6 & 6 & 8 & 8 \\
\hline Spines & Present & Present ${ }^{c}$ & Absent & Absent & Absent & Absent & Absent \\
\hline $\begin{array}{l}\text { Relation of tail length } \\
(\mathrm{LT}) \text { to head-body } \\
\text { length (HB) }\end{array}$ & $\mathrm{LT}<=>\mathrm{HB}$ & $\mathrm{LT} \leq \mathrm{HB}$ & $\mathrm{LT}>>\mathrm{HB}$ & $\mathrm{LT}<=>\mathrm{HB}$ & $L T>H B$ & $\mathrm{LT} \leq \mathrm{HB}$ & $\mathrm{LT}<<\mathrm{HB}$ \\
\hline Rostrum & Short & Short & Long & Long & $\begin{array}{l}\text { Long, rostral tube } \\
\text { developed }\end{array}$ & Moderate & Moderate \\
\hline Interorbit & $\begin{array}{l}\text { Hourglass-shaped or } \\
\text { slightly convergent, } \\
\text { with rounded margins }\end{array}$ & $\begin{array}{l}\text { Convergent, with } \\
\text { beaded margins }\end{array}$ & $\begin{array}{l}\text { Hourglass-shapede, } \\
\text { with beaded margins }\end{array}$ & $\begin{array}{l}\text { Hourglass-shaped, } \\
\text { with rounded margins }\end{array}$ & $\begin{array}{l}\text { Hourglass-shaped, } \\
\text { with rounded margins }\end{array}$ & $\begin{array}{l}\text { Hourglass-shaped, } \\
\text { with rounded margins }\end{array}$ & $\begin{array}{l}\text { Symmetrically } \\
\text { constricted, with } \\
\text { parallel margins }\end{array}$ \\
\hline Palate & Typically short & Long & Short & Short & Short & Short & Long \\
\hline Mesopterygoid fossa & Not fenestrated & Not fenestrated & Not fenestrated & Not fenestrated & Not fenestrated & Fenestrated & Fenestrated \\
\hline Alisphenoid strut & Typically present & Present & Absent & Present & $?$ & Typically present & Present \\
\hline Tegmen tympani & Overlaps squamosal & Overlaps squamosal & Overlaps squamosal & Overlaps squamosal & Overlaps squamosal & Overlaps squamosal & $\begin{array}{l}\text { Does not overlap } \\
\text { squamosal }\end{array}$ \\
\hline Carotid circulation & Pattern 1 & Pattern 3 & Pattern 1 & Pattern 1 & Pattern 1 & Pattern 1 & Pattern 3 \\
\hline Capsular process & Present & Present & Absent & Absent & Absent & Typically present & Present \\
\hline Retromolar fossa & Enlarged & Enlarged & Not enlarged & Not enlarged & Not enlarged & Not enlarged & Not enlarged \\
\hline Molar design & $\begin{array}{l}\text { Intermediate to } \\
\text { alternate, crested }\end{array}$ & Opposite, crested & Opposite, crested & Opposite, crested & Opposite, crested & $\begin{array}{l}\text { Intermediate, crested } \\
\text { to terraced }\end{array}$ & Alternate, plane \\
\hline Anteromedian flexus & Patent & Patent & Patent & Patent & Patent & Patent & Not patent \\
\hline Mesoloph on M1 & Present, small & Present, large & Present, large & Present, large & Present, large & Present, small & Absent \\
\hline $\mathrm{M} 3$ reduction to $\mathrm{M} 2$ & Much reduced & Moderately & Weakly & Moderately & $\begin{array}{l}\text { Moderately } \\
\text { to reduced }\end{array}$ & Much reduced & Weakly \\
\hline Incisors & Orthodont to proodont & Orthodont & Opisthodont & Opisthodont & Opisthodont & Typically opisthodont & Opisthodont \\
\hline Incisive foramina & $\begin{array}{l}\text { Reaching } \\
\text { anterior face M1 }\end{array}$ & Very short & $\begin{array}{l}\text { Reaching anterior } \\
\text { face M1 }\end{array}$ & $\begin{array}{l}\text { Reaching anterior } \\
\text { face } M 1\end{array}$ & $\begin{array}{l}\text { Reaching anterior } \\
\text { face } \mathrm{M} 1\end{array}$ & Reaching protocone M1 & $\begin{array}{l}\text { Reaching } \\
\text { protocone M1 }\end{array}$ \\
\hline Subsquamosal foramen & Present & Present & Absent & Present & Present & Present & Present \\
\hline Number of ribs & 12 & 13 & 12 & 13 & 13 & 13 & 12 \\
\hline Gall bladder & Absent & Absent & Present & Present & Present & Typically present ${ }^{\mathrm{h}}$ & Present \\
\hline
\end{tabular}

anguinal, abdominal, and postaxial pairs (Pardiñas, unpublished data). ${ }^{\mathrm{b}}$ Based on Rhagomys longilingua, after Luna and Patterson (2003). ${ }^{\mathrm{c}}$ Rhagomys rufescens lacks spines (cf. Luna and Patterson 2003). ${ }^{\mathrm{d}}$ Data from Voss

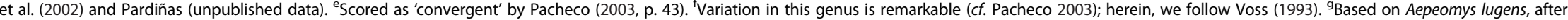

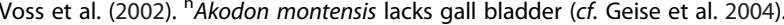


phylogenetic position is assessed, it is unclear whether they in fact represent additional main sigmodontine lineages almost endemic to the Atlantic forest or simply constitute additional genera belonging to other already identified main lineages of the Sigmodontinae either already known from the Atlantic forest or not. Whatever this result is, the finding that at least three unrelated main sigmodontine lineages, those currently represented by Abrawayaomys, Delomys, and Juliomys, are endemic to the southern Atlantic forest supports early claims (Smith and Patton 1999; D'Elía 2003b; see also Salazar-Bravo et al. 2013) highlighting the role of the Atlantic forest in harboring sigmodontine phylogenetic diversity. Future studies should be designed to test if these lineages originated in the Atlantic forest or simply invaded it after originating elsewhere.

Spines of varying hardness and architectures are present in several rodents (Chernova and Kuznetsov 2001) and are conspicuous in some Neotropical groups, such as porcupines (Erethizontidae) and spiny rats (Echimyidae). The vast majority of sigmodontine rodents have soft fur, but a few genera and species have dorsal spines. These spines are present in both species of Abrawayaomys, both species of Scolomys, all eight species of Neacomys, but only in one of the two species of Rhagomys. Rhagomys longilingua from the Andes has spiny fur, but Rhagomys rufescens from the Atlantic forest has soft fur (Luna and Patterson 2003). Considering the phylogeny portrayed here, we concluded that these spines are the result of evolutionary convergence, and this trait evolved at least four times in sigmodontines (Figure 1). None of these four genera are sister groups, and each one of them shares a more recent common ancestor with soft-furred genera or species (in the case of Rhagomys). The functional significance of spines remains unknown. Unlike porcupine quills, spines of muroid or echimyid rodents are insufficiently rigid to provide much protection against predators, including snakes, birds, and mammals, which are known to prey heavily on many spiny species (Hoey et al. 2004). Patterson and Velazco (2008) suggested a thermoregulatory interpretation based on the geographic distribution of echimyid rodents: the spiniest members occur in tropical lowland forests, while many of the softest-haired members of the family range into high elevations or latitudes, but they also noted several exceptions. The same pattern does not occur in sigmodontine rodents, since soft-furred taxa occur at all latitudes and elevations throughout the Neotropics. Regarding spiny taxa, both Neacomys and Scolomys are lowland forest genera found at lower latitudes (Patton et al. 2000); Abrawayaomys also occurs in lowland forests, but at higher latitudes in the Atlantic forest (Pardiñas et al. 2009b); and the spiny $R$. longilingua is found in Andean cloud forests at 1,900 2,100 $\mathrm{m}$ in elevation (Luna and Patterson 2003), while the soft-furred $R$. rufescens occurs mostly in montane Atlantic forest at $500 \sim 1,000 \mathrm{~m}$ in elevation (Steiner-Souza et al. 2008). Therefore, we still lack robust hypotheses for the ecological role, if any, of spiny fur in sigmodontine rodents, but the character distribution mapped on a phylogenetic tree presented here is the first step toward understanding its evolutionary importance.

\section{Conclusions}

Phylogenetic analyses show that Abrawayaomys constitutes the single representative so far known of one of the main lineages of the radiation of Sigmodontinae. In addition, it differs from all other Atlantic forest sigmodontine rodents by having a unique combination of morphological character states. Therefore, in formal classifications, it should be regarded as a Sigmodontinae incertae sedis.

Finally, the observed variation of the four Cyt $b$ sequences analyzed and their geographic pattern, where the one gathered from the northernmost-collected specimen (in the state of Minas Gerais) was the most divergent, are enticing to further explore variation of a larger sample of $A$. ruschii sequences. Such a study would clarify into which of the already known phylogeographic patterns of Atlantic forest mammals (e.g., Colombi et al. 2010;Ventura et al. 2012; Valdez and D'Elía 2013; see reviews in Martins 2011; Costa and Leite 2012) would $A$. ruschii fit, or if this species presents a so far undescribed pattern. Similarly, such a study would help assess the alpha diversity of Abrawayaomys (Pardiñas et al. 2009b). Now, that $A$. ruschii is becoming more frequent in specimen collections, such a study seems feasible.

\section{Competing interests}

The authors declare that they have no competing interests.

\section{Authors' contributions}

$\mathrm{KV}$ and GD conceived and coordinated the study. KV, MJJS, LG, YLRL, and YY $Y$ gathered the DNA sequences. UFJP and YLRL performed the morphological assessment. GD carried out the phylogenetic analyses. GD, KV, and UFJP drafted the manuscript. All authors read and approved the final manuscript.

\section{Acknowledgements}

We thank André Almeida Cunha, Arlei Marcili, Caroline Cotrim Aires, Laerte Bento Viola, Marcelo Passamani, Patricia B. Bertola, Renata Pardini, and Sandra Favorito for support with fieldwork and collecting specimens, and Juliana F. Justino for producing some of the DNA sequences. Two anonymous reviewers provided valuable comments on an earlier version of this contribution. This work was supported by Conselho Nacional de Desenvolvimento Científico e Tecnológico, Coordenação de Aperfeiçoamento de Pessoal de Nível Superior (CAPES-BEX 3795/08-0) (to LG), Fundação de Amparo a Pesquisa do Estado de São Paulo BP.PD 2009/54300-0 (to KV), JP 05/07553-8 (to MJJS), Fundação de Amparo à Pesquisa do Espírito Santo (to YLRL), Fundação de Amparo do Estado do Rio de Janeiro (FAPERJ-E-26/111.525/2010) (to LG), PICT (Agencia) 2008-547 (to UFJP), Fondo Nacional de Desarrollo Científico y Tecnólogico 1110737 (to GD), and MECESUP AUS1203 (to GD).

\section{Author details}

'Departamento de Genética e Biologia Evolutiva, Instituto de Biociências, Universidade de São Paulo, São Paulo 05508-090, Brazil. ²Laboratório de Ecologia e Evolução, Instituto Butantan, São Paulo 05503-000, Brazil. 3Laboratório de Mastozoologia, Departamento de Zoologia, Instituto de Biologia, Universidade do Estado do Rio de Janeiro, Rio de Janeiro 
20550-013, Brazil. “Laboratório de Mastozoologia e Biogeografia, Departamento de Ciências Biológicas, Centro de Ciências Humanas e Naturais, Universidade Federal do Espírito Santo, Vitória 29075-910, Brazil. ${ }^{5}$ Unidad de Investigación Diversidad, Sistemática y Evolución, Centro Nacional Patagónico, Puerto Madryn 9120, Argentina. Instituto de Cs. Ambientales y Evolutivas, Facultad de Ciencias, Universidad Austral de Chile, Valdivia 5090000, Chile.

\section{Received: 18 February 2013 Accepted: 30 October 2013} Published: 9 December 2013

\section{References}

Alarcón O, D'Elía G, Lessa E, Pardiñas UFJ (2011) Phylogeographic structure of the fossorial long-clawed mouse Chelemys macronyx (Cricetidae: Sigmodontinae). Zool Stud 50:682-688

Alvarado-Serrano D, D'Elía G (2013) A new genus for the Andean mice Akodon latebricola and A. bogotensis (Rodentia: Sigmodontinae). J Mamm 94:995-1015

Andrades-Miranda J, Zanchin NIT, Oliveira LFB, Langguth A, Mattevi MS (2000) Cytogenetic studies in nine taxa of the genus Oryzomys (Rodentia, Sigmodontinae) from Brazil. Mammalia 65:461-472

Bonvicino CR, Lindbergh SM, Barros M, Bezerra AMR (2012) The eastern boundary of the Brazilian Cerrado: a hotspot region. Zool Stud 51:1207-1218

Braun JK (1993) Systematic relationships of the tribe Phyllotini (Muridae: Sigmodontinae) of South America. Oklahoma Museum of Natural History, Norman, OK

Carleton MD (1973) A survey of gross stomach morphology in New World cricetine (Rodentia, Muroidea) with comments on functional interpretations. Misc Publ Mus Zool Univ Michigan 146:1-43

Chernova OF, Kuznetsov GV (2001) Structural features of spines in some rodents (Rodentia: Myomorpha, Hystricomorpha). Biol Bull 28:371-382

Colombi VH, Lopes SR, Fagundes V (2010) Testing the Rio Doce as a riverine barrier in shaping the Atlantic rainforest population divergence in the rodent Akodon cursor. Genet Mol Biol 33:785-789

Costa LP, Leite YL (2012) Historical fragmentation shaping vertebrate diversification in the Atlantic forest biodiversity hotspot. In: Patterson BD, Costa LP (eds) Bones, clones, and biomes: the history and geography of recent Neotropical mammals. Univ. of Chicago Press, Chicago, pp 283-306

D'Elía G (2003a) Rats, mice, and relatives IV: Sigmodontinae. In: Kleiman DG, Geist V, Hutchins M, McDade MC (eds) Mammals, vol vol, 16 of Grzimek's animal life encyclopedia, 1st ed. Thomson-Gale, Farmington Hills, MI, pp 263-279

D'Elía G (2003b) Phylogenetics of sigmodontinae (Rodentia, Muroidea, Cricetidae), with special reference to the akodont group, and with additional comments on historical biogeography. Cladistics 19:307-323

D'Elía G, Pardiñas UFJ (2007) Putting names to the phylogenetic diversity of Neotropical sigmodontine rodents: new genera for known species. Mammalia 71:143-145

D'Elía G, González EM, Pardiñas UFJ (2003) Phylogenetic analysis of sigmodontine rodents (Muroidea), with special reference to the akodont genus Deltamys. Mamm Biol 68:351-364

D'Elia G, Luna L, Gonzalez EM, Patterson BD (2006a) On the Sigmodontinae radiation (Rodentia, Cricetidae): an appraisal of the phylogenetic position of Rhagomys. Mol Phylogenet Evol 38:558-564

D'Elia G, Ojeda AA, Mondaca F, Gallardo MH (2006b) New data of the tong-clawed mouse Pearsonomys annectens (Cricetidae, Sigmodontinae) and additional comments on the distinctiveness of Pearsonomys. Mamm Biol 71:39-51

D'Elía G, Pardiñas UFJ, Teta P, Patton JL (2007) Definition and diagnosis of a new tribe of sigmodontine rodents (Cricetidae: Sigmodontinae), and a revised classification of the subfamily. Gayana 71:187-194

Engel SR, Hogan KM, Taylor JF, Davis SK (1998) Molecular systematics and paleobiogeography of the South-American sigmodontine rodents. Mol Biol Evol 15:35-49

Feijoo M, D'Elía G, Pardiñas UFJ, Lessa EP (2010) Systematics of the southern Patagonian-Fueguian endemic Abrothrix lanosus (Rodentia: Sigmodontinae): phylogenetic position, karyotypic and morphological data. Mamm Biol 75:122-137

Felsenstein J (1981) Evolutionary trees from DNA sequences: a maximum likelihood approach. J Mol Evol 17:368-376

Finotti R, Cunha A, Cerqueira R (2003) Alimentação macroscópica do trato digestivo de Abrawayaomys ruschii. Abstracts of the II Congresso Brasileiro de Mastozoologia, Belo Horizonte, Brazil
Geise L, Weksler M, Bonvicino CR (2004) Presence or absence of gall bladder in some Akodontini rodents (Muridae, Sigmodontinae). Mamm Biol 69:210-214

Hershkovitz P (1962) Evolution of Neotropical cricetine rodents (Muridae) with special reference to the phyllotine group. Fieldiana Zool 46:1-524

Hoey KA, Wise RR, Adler GH (2004) Ultrastructure of echimyid and murid rodent spines. J Zool 263:307-315

Jobb G (2008) Treefinder version of April 2008. Available at http://www.treefinder. de/. Accessed 31 June 2011

Jobb G, Haeseler A, Strimmer K (2004) TREEFINDER: a powerful graphical analysis environment for molecular phylogenetics. BMC Evol Biol 4:18

Luna L, Patterson BD (2003) A remarkable new mouse (Muridae: Sigmodontinae) from southeastern Peru: with comments on the affinities of Rhagomys rufescens. Fieldiana Zool 101:1-24

Martínez JJ, Ferro LI, Mollerach Ml, Barquez RM (2012) The phylogenetic relationships of the Andean swamp rat genus Neotomys (Rodentia, Cricetidae, Sigmodontinae) based on mitochondrial and nuclear markers. Acta Theriol 57:277-287

Martins FD (2011) Historical biogeography of the Brazilian Atlantic forest and the Carnaval-Moritz model of Pleistocene refugia: what do phylogeographical studies tell us? Biol J Linn Soc 104:499-509

Musser GG, Carleton MD (2005) Superfamily Muroidea. In: Wilson DE, Reeder DM (eds) Mammal species of the world: a taxonomic and geographic reference, 3rd edn. Johns Hopkins Univ. Press, Baltimore, MD, pp 894-1531

Myers P, Carleton MD (1981) The species of Oryzomys (Oligoryzomys) in Paraguay and the identity of Azara's "rat sixième ou rat à tarse noir". Misc Publ Mus Zool Univ Michigan 161:1-41

Pacheco VR (2003) Phylogenetic analyses of the Thomasomyini (Muroidea: Sigmodontinae) based on morphological data, PhD thesis. City Univ. of New York, New York

Parada A, Pardiñas UFJ, Salazar-Bravo J, D'Elía G, Palma ER (2013) Dating an impressive Neotropical radiation: molecular time estimates for the Sigmodontinae (Rodentia) provide insights into its historical biogeography. Mol Phylogen Evol 66:960-968

Pardiñas UFJ, D'Elía G, Cirignoli S (2003) The genus Akodon (Muroidea: Sigmodontinae) in Misiones, Argentina. Mamm Biol 68:129-143

Pardiñas UFJ, D'Elía G, Teta P (2009a) Una introducción a los mayores sigmodontinos vivientes: revisión de Kunsia Hershkovitz, 1966 y descripción de un nuevo género (Rodentia: Cricetidae). Arq Mus Nacl Rio de Janeiro 66:509-594

Pardiñas UFJ, Teta P, D'Elía G (2009b) Taxonomy and distribution of Abrawayaomys (Rodentia: Cricetidae), an Atlantic forest endemic with the description of a new species. Zootaxa 2128:39-60

Passamani M, Cerboncini RAS, Oliveira JE (2011) Distribution extension of Phaenomys ferrugineus (Thomas, 1894), and new data on Abrawayaomys ruschii Cunha and Cruz, 1979 and Rhagomys rufescens (Thomas, 1886), three rare species of rodents (Rodentia: Cricetidae) in Minas Gerais, Brazil. CheckList 7:827-831

Patterson BD, Velazco PM (2008) Phylogeny of the rodent genus /sothrix (Hystricognathi, Echimyidae) and its diversification in Amazonia and the eastern Andes. J Mamm Evol 15:181-201

Patton JL, da Silva MNF, Malcolm JR (2000) Mammals of the Rio Juruá and the evolutionary and ecological diversification of Amazonia. Bull Am Mus Nat Hist 244:1-306

Percequillo AR, Weksler M, Costa LP (2011) A new genus and species of rodent from the Brazilian Atlantic forest (Rodentia: Cricetidae: Sigmodontinae: Oryzomyini), with comments on oryzomyine biogeography. Zool J Linn Soc 161:357-390

Pereira LG, Geise L, Cunha AA, Cerqueira R (2008) Abrawayaomys ruschii Cunha \& Cruz, 1979 (Rodentia, Cricetidae) no estado do Rio de Janeiro, Brasil., pp 33-40

Pine RH, Timm RM, Weksler M (2012) A newly recognized clade of trans-Andean Oryzomyini (Rodentia: Cricetidae), with description of a new genus. J Mamm 93:851-868

Rannala B, Yang ZH (1996) Probability distribution of molecular evolutionary trees: a new method of phylogenetic inference. J Mol Evol 43:304-311

Reig OA (1980) A new fossil genus of South American cricetid rodents allied to Wiedomys, with an assessment of the Sigmodontinae. J Zool (Lond) $192 \cdot 257-281$

Reig OA (1984) Distribuicao geografica e historia evolutiva dos roedores muroideos sulamericanos (Cricetidae: Sigmodontinae). Rev bras Genet 7:333-365 
Reig OA (1986) Diversity patterns and differentiation of high Andean rodents. In: Vuilleumier F, Monasterio M (eds) High altitude tropical biogeography. Oxford Univ. Press and American Museum of Natural History, New York and Oxford, UK, pp 404-439

Reig OA (1987) An assessment of the systematics and evolution of the Akodontini, with the description of new fossil species of Akodon (Cricetidae, Sigmodontinae). In: Patterson BD, Timm RM (eds) Studies in Neotropical Mammalogy, Fieldiana, Zool, 39:347-399

Ronquist F, Huelsenbeck JP (2003) MrBayes 3: Bayesian phylogenetic inference under mixed models. Bioinformatics 19:1572-1574

Salazar-Bravo J, Yates TL (2007) A new species of Thomasomys (Cricetidae: Sigmodontinae) from central Bolivia. In: Kelt DA, Lessa EP, Salazar-Bravo J, Patton JL (eds) The quintessential naturalist: honoring the life and legacy of Oliver P. Pearson, 134th edn. Univ. of California Publications in Zoology, Berkeley, pp 747-774

Salazar-Bravo J, Pardiñas UFJ, D'Elía G (2013) A phylogenetic appraisal of Sigmodontinae (Rodentia, Cricetidae) with emphasis on phyllotine genera: systematics and biogeography. Zool Scr 42:250-261

Smith MF, Patton JL (1999) Phylogenetic relationships and the radiation of sigmodontine rodents in South America: evidence from cytochrome b. J Mamm Evol 6:89-128

Steiner-Souza F, Cordeiro-Estrela P, Percequillo AR, Testoni AF, Althoff SL (2008) New records of Rhagomys rufescens (Rodentia: Sigmodontinae) in the Atlantic forest of Brazil. Zootaxa 1824:28-34

Steppan SJ (1995) Revision of the tribe Phyllotini (Rodentia: Sigmodontinae), with a phylogenetic hypothesis for the Sigmodontinae. Fieldiana Zool 80:1-112

Steppan SJ, Adkins RM, Anderson J (2004) Phylogeny and divergence-date estimates of rapid radiations in muroid rodents based on multiple nuclear genes. Syst Biol 53:533-553

Tamura K, Peterson D, Peterson N, Stecher G, Nei M, Kumar S (2011) MEGA5: molecular evolutionary genetics analysis using maximum likelihood, evolutionary distance, and maximum parsimony methods. Mol Biol Evol 28:2731-2739

Teta P, D'Elía G, Pardiñas UFJ, Jayat JP, Ortíz PE (2011) Phylogenetic position and morphology of Abrothrix illutea Thomas, 1925, with comments on the incongruence between gene trees of Abrothrix (Rodentia, Cricetidae) and their implications for the delimitation of the genus. Zoosyst Evol 87:227-241

Thompson JD, Gibson TJ, Plewniak F, Jeanmougin F, Higgins HG (1997) The Clustal $X$ windows interface: flexible strategies for multiple sequence alignment aided by quality analysis tools. Nucl A Res 24:4876-4882

Valdez L, D'Elía G (2013) Differentiation in the Atlantic forest: phylogeography of Akodon montensis (Rodentia, Sigmodontinae) and the Carnaval-Moritz model of Pleistocene refugia. J Mamm 94:911-922

Ventura K, Sato-Kuwabara Y, Fagundes V, Geise L, Leite YLR, Silva MJJ, YonenagaYassuda Y, Rodrigues MT (2012) Phylogeographic structure and karyotypic diversity of the Brazilian shrew mouse (Blarinomys breviceps, Sigmodontinae) in the Atlantic forest. Cytogenet Genome Res 138:19-30

Voss RS (1993) A revision of the Brazilian muroid rodent genus Delomys with remarks on "thomasomyine" characters. Am Mus Novit 3073:1-44

Voss RS, Gomez-Laverde M, Pacheco V (2002) A new genus for Aepeomys fuscatus Allen, 1912 and Oryzomys intectus Thomas, 1921: enigmatic murid rodents from Andean cloud forests. Am Mus Novit 3373:42

Weksler M (2003) Phylogeny of Neotropical oryzomyine rodents (Muridae: Sigmodontinae) based on the nuclear IRBP exon. Mol Phylogenet Evol 29:331-349

Yonenaga-Yassuda Y, Prado RC, Mello DA (1987) Supernumerary chromosomes in Holochilus brasiliensis and comparative cytogenetic analysis with Nectomys squamipes (Cricetidae, Rodentia). Bras J Genet 2:209-220

doi:10.1186/1810-522X-52-55

Cite this article as: Ventura et al.: The phylogenetic position of the enigmatic Atlantic forest-endemic spiny mouse Abrawayaomys (Rodentia: Sigmodontinae). Zoological Studies 2013 52:55.

\section{Submit your manuscript to a SpringerOpen ${ }^{\odot}$ journal and benefit from:}

- Convenient online submission

- Rigorous peer review

- Immediate publication on acceptance

- Open access: articles freely available online

- High visibility within the field

- Retaining the copyright to your article

Submit your next manuscript at $\gg$ springeropen.com 